\title{
Climate Change in Brazilian Cities: Policy Strategies and Responses to Global Warming
}

\author{
Fabiana Barbi, and Leila da Costa Ferreira
}

\begin{abstract}
Local governments play a key role developing and implementing public policies to mitigate and to adapt to climate change. This paper aims to analyze how Brazilian cities are responding to climate change in terms of policy strategies and instruments. The methodological steps cover five characteristics of these policies: 1. Mitigation goals; 2 . Adaptation actions; 3 . Participation of different segments of society; 4. Multi-sectorial policy implementation; 5. Government participation in networks related to climate change. Our findings suggest that local climate policies in Brazil are isolated initiatives within the national context. The strongest Brazilian policies with both mitigation and adaptation actions counted on a previous mobilization for the climate issue involving different actors from several segments of the society. These cities have also participated in transnational cooperation networks related to climate change. Certainly these factors favored the adoption of laws by those governments. Most laws have multi-sectorial nature of implementation, an important factor considering the climate issue that is related to different sectors of government action.
\end{abstract}

Index Terms-Adaptation, Brazil, climate change policy, mitigation.

\section{INTRODUCTION}

The warning was done: the Earth's average temperature may not increase more than $2^{\circ} \mathrm{C}$ compared to preindustrial times, by the end of this century, or climate change will go completely out of control [1]. Climate change is characterized, therefore, as one of the major global challenges of the 21 st century.

Considering that more than half the world population lives in cities and two thirds of humanity is expected to be living in urban areas by 2030, it is understood that the issue of climate change has an important local dimension since many human activities that contribute to these changes generally occur at the local level, where the impacts of these changes are also felt [2]. Fast growing cities in developing countries are especially vulnerable to the impacts of climate change [3]. In such circumstances, local governments play a key role developing and implementing public policies to mitigate and to adapt in response to these changes [4].

Mitigation includes all human activities that aim to reduce emissions or enhance greenhouse gases (GHG) sinks [5], [1].

Manuscript received November 23, 2012; revised January 31, 2013.

Fabiana Barbi is with the Centre of Environmental Studies and Research (NEPAM) at the State University of Campinas (UNICAMP), Brazil (e-mail:fabarbi@gmail.com).

Leila da Costa Ferreira is with the Institute of Philosophy and Human Sciences (IFCH) and Centre of Environmental Studies and Research (NEPAM) at the State University of Campinas (UNICAMP), Brazil. (e-mail: leilacf@unicamp.br).
Besides energy, other sectors are also involved, such as transport, construction, industry, agriculture, forestry and waste. Adaptation in the context of climate change refers to any adjustment that occurs in natural or human systems in response to actual or anticipated impacts of climate change, aiming to deal with the consequences, moderate damage or exploit beneficial opportunities [6], [5], [1]. The main sectors involved in the adaptation policies are: water resources, agriculture, infrastructure, health, tourism, transport and energy. Thus, climate policy involves several government sectors.

The issue of climate policy is not about either mitigating climate change or adapting to it anymore. Since the early impacts of climate change are already being observed in natural systems, adaptation becomes a necessity [7], [8]. However, relying solely on adaptation can lead to a climate change of such magnitude in which effective adaptation is only possible to a very high social and economic cost. Therefore, it is understood that both mitigation and adaptation are essential in reducing the risks of climate change [9], [10].

Several local governments have been successful in implementing programs and actions to tackle climate change [11]. A growing number of local governments have joined national and transnational cooperation networks, such as: 'CCP - Cities for Climate Protection' from ICLEI - Local Governments for Sustainability; the C40 Cities, a group that includes the largest cities in the world committed to tackling climate change; 'AMICA' Alliance of European Cities for Climate, among others. These efforts involve more than a thousand local governments around the world aiming to support and encourage local governments to adopt policies addressing climate change. The development of an explicit urban approach to climate governance is due to the emergence of these networks since the early 90s. They provided inspiration to local governments, concrete projects, access to funding, examples of best practices and informal structures of recognition and rewards, which led to significant responses of governments around the world [12].

In this context, this paper analyses how Brazilian cities are responding to climate change in terms of policy strategies and instruments. Cities with specific legislation to address the climate issue were surveyed through searches on some Brazilian key websites, such as http://www.cetesb.sp. gov.br/mudancas-climaticas/proclima/Legisla $\% \mathrm{C} 3 \% \mathrm{~A} 7 \% \mathrm{C}$ 3\%A3o/90-Municipal, http://www.oc.org.br/index.php?page $=$ Conteudo\&id $=113$, and www.google.com by with key words: municipal, policy, climate, change. Afterwards, the following characteristics related to climate governance were analyzed in these policies: 
1) Climate change mitigation: goals to reduce $\mathrm{GHG}$ emissions;

2) Adaptation to climate change impacts;

3) Articulation among different actors: presence of institutional structures that include the participation of different segments of society in the design of the policy;

4) Multi-sectoriality in the implementation of the law by different government sub-sectors related to the climate issue;

5) Government participation in transnational networks related to climate change.

\section{Responses to Climate CHANGE IN BRAZILIAN Cities}

The first Brazilian city to pass a legislation related to climate change was Palmas, in Tocantins, in 2003. Although it was not the first climate policy in Brazil, Sao Paulo's policy, adopted in 2009, was a pioneer in establishing goals for reducing GHG emissions. It played an important role influencing the approval of the São Paulo State Policy, which in turn also influenced the national policy on climate change. All of these policies were approved in 2009. Other cities that have laws establishing municipal climate policy in Brazil are: Belo Horizonte, in Minas Gerais, Feira de Santana, in Bahia and Rio de Janeiro, in Rio de Janeiro, all of them approved in 2011. Fig. I shows all Brazilian cities with climate policies.

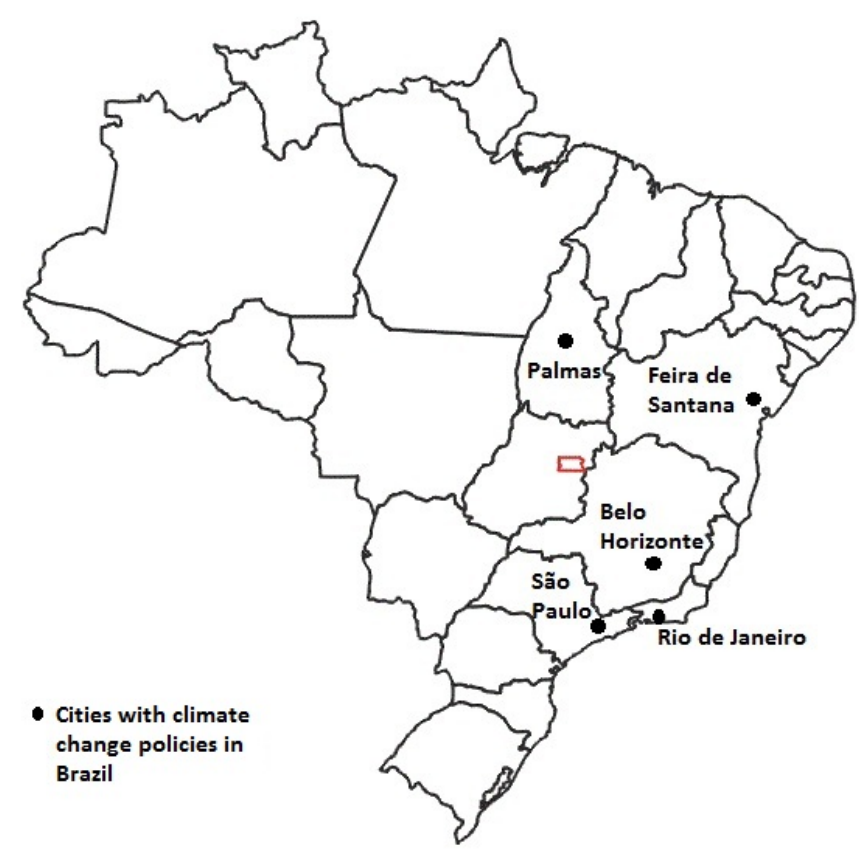

Fig. 1. Brazilian Cities with Climate Change Policies.

\section{A. Mitigation and Adaptation to Climate Change}

The policies of Belo Horizonte, Rio de Janeiro and São Paulo set concrete targets for reducing GHG emissions and deadlines. They have done their GHG emissions inventory and are planning and implementing actions to mitigate emissions. Rio de Janeiro and São Paulo also propose adaptation plans to climate change impacts. The law of Feira de Santana and Palma do not set specific targets and do not propose any adaptation plan.

\section{B. Participation in the Policy Design}

In Sao Paulo, the articulation to design the climate policy started in 2005 with the creation of the Municipal Committee on Climate Change and Sustainable Economy, aiming to promote and encourage mitigation actions. In the case of Belo Horizonte, the discussions around the climate policy began in 2006 with the creation of the Municipal Committee on Climate Change and Eco-efficiency, under the municipal government. Similarly, in Rio de Janeiro, the discussions about the law were supported by the Forum on Climate Change, since 2009. All these structures count on the participation of different actors such as different sectors of municipal and state governments, NGOs, research institutions and universities and private sectors representatives. In Feira de Santana, the law plans the creation of a Climate Change Forum.

\section{Policy Implementation}

In Belo Horizonte, São Paulo and Rio de Janeiro climate governance is multi-sectorial and climate change is a cross-cutting theme to the cities' actions. In this case, these cities have a multi-sectorial institutional structure prior to the adoption of the law that involves different government sectors. In Feira de Santana the policy implementation is linked to only one department, the Environment. In these cities it is expected the participation of society in its different sectors to implement the policy. In Palmas, the policy implementation is in charge of the State Environment Department.

\section{Climate Change Networks}

Belo Horizonte, Sao Paulo and Rio de Janeiro are ICLEI members and have joined the CCP campaign. Palmas joined the campaign from 2002-2004. Under the campaign, Belo Horizonte and Sao Paulo participated in the project "Policies for Sustainable Construction" whose aim was to establish the commitment of local governments for the development and implementation of sustainable construction, with a focus on energy efficiency and low carbon technologies. These cities also joined another project, "Local Renewables Initiative", aiming to promote the generation and use of renewable energy and energy efficiency. São Paulo also participated in the project "Green and Healthy Environments", which resulted in the text of the municipal policy on climate change, and in the project "Fostering Sustainable Public Procurement in Brazil", aiming to change the government consumption patterns [13].

The city of Rio de Janeiro was the first ICLEI's headquarters in Brazil from 2000 to mid-2006 and Sao Paulo has been the current headquarters since 2006. Furthermore, these two cities are also part of the C-40 cities network and hosted summit meetings of the organization in 2011 and 2012 respectively.

\section{FINAL COMMENTS}

The data presented about climate policies in Brazilian cities is summarized in Table 1. Most policies in Brazilian cities were approved after 2009, a moment when the climate change issue was in the international political agenda. The policies of Rio de Janeiro and São Paulo are stronger since they determine both mitigation and adaptation actions and 
targets. In these cities, there was a mobilization for the climate issue before the law was passed, with the participation of different actors of different segments as well as in Belo Horizonte, whose policy is more mitigatory. Besides, most cities are involved in international cooperation networks related to climate change, emphasizing the importance of these networks for climate policies implementation at the local level. Most policies address the climate issue in a multi-sectorial way in the policy implementation, a necessary feature for tackling the problem.

TABLE I: CHARACTERISTICS OF CLIMATE CHANGE POLICY IN BRAZILIAN CITIES

\begin{tabular}{|c|c|c|c|c|c|}
\hline City & $\begin{array}{c}\text { Belo } \\
\text { Horizonte }\end{array}$ & $\begin{array}{c}\text { Feira de } \\
\text { Santana }\end{array}$ & Palmas & $\begin{array}{c}\text { Rio de } \\
\text { Janeiro }\end{array}$ & $\begin{array}{c}\text { São } \\
\text { Paulo }\end{array}$ \\
\hline $\begin{array}{c}\text { Year of policy } \\
\text { approval }\end{array}$ & 2011 & 2011 & 2003 & 2011 & 2009 \\
\hline $\begin{array}{c}\text { Set targets to } \\
\text { reduce GHG }\end{array}$ & $\mathrm{X}$ & - & - & $\mathrm{X}$ & $\mathrm{X}$ \\
\hline $\begin{array}{c}\text { Adaptation } \\
\text { Plan }\end{array}$ & - & - & - & $\mathrm{X}$ & $\mathrm{X}$ \\
\hline $\begin{array}{c}\text { Participation of } \\
\text { different actors in } \\
\text { the policy design }\end{array}$ & $\mathrm{X}$ & - & - & $\mathrm{X}$ & $\mathrm{X}$ \\
\hline $\begin{array}{c}\text { Multi-sectorial } \\
\text { policy execution }\end{array}$ & $\mathrm{X}$ & $\mathrm{X}$ & - & $\mathrm{X}$ & $\mathrm{X}$ \\
\hline $\begin{array}{c}\text { Participation in } \\
\text { transnational } \\
\text { Climate networks }\end{array}$ & $\mathrm{X}$ & - & $\mathrm{X}$ & $\mathrm{X}$ & $\mathrm{X}$ \\
\hline
\end{tabular}

\section{CONCLUSION}

There is a growing movement at international level of cities responding to climate change. Local governments have led responses to climate change in the world. In Brazil it is not different. This kind of action began at the municipal level of government, extending to the state level and only then arrived at the federal level. In this sense the municipal climate policy of São Paulo is highlighted: it played a key role setting GHG reduction targets and influenced the adoption of state law, which in turn had strong influence on the federal law.

However, local climate policies in Brazil are isolated initiatives within the national context. Thus, not all laws address both aspects of climate policy: mitigation and adaptation. The strongest Brazilian policies involving these two aspects counted on a previous mobilization for the climate issue connecting different actors from several segments of the society. These cities have also participated in transnational cooperation networks related to climate change. Certainly these factors favored the adoption of laws by those governments. This kind of involvement brings many benefits to the cities because there is a great exchange of experiences with cities around the world in relation to actions and strategies for tackling climate change. Moreover, when occupying these positions, these cities also establish concrete and specific goals and objectives about the issue.

Although few cities in Brazil count on a climate policy, the analyzed experiences are important initiatives to tackle climate change in the country and should be expanded to other cities.

\section{REFERENCES}

[1] IPCC - Intergovernmental Panel on Climate Change, "Summary for Policymakers" in Climate Change 2007: Mitigation, Contribution of Working Group III to the Fourth Assessment Report of the Intergovernmental Panel on Climate Change, B. Metz, O. R. Davidson, P. R. Bosch, R. Dave, and L. A. Meyer, Eds., Cambridge University Press, Cambridge, United Kingdom and New York, NY, USA, 2007.

[2] T. J. Wilbanks and R. W. Kates, "Global Change in Local Places: How Scales Matters," Climatic Change, vol. 43, pp. 601-628, 1999.

[3] D. J. Hogan and E. Marandola, População e mudança climática. Dimensões humanas das mudanças ambientais globais, NEPO/ Unicamp, Brasília: UNFPA, 2009.

[4] L. C. Ferreira et al., "Governing Climate Change in Brazilian Coastal Cities: Risks and Strategies," Journal of US-China Public Administration, vol. 8, no.1, pp. 51-65, 2011.

[5] R. J. T. Klein, E. L. F. Schipper and S. Dessai, "Integrating mitigation and adaptation into climate and development policy: three research questions," Environmental Science \& Policy, vol. 8, 2005.

[6] W. N. Adger, S. Huq, K. Brown, D. Conway and M. Hulme, "Adaptation to climate change in the developing world," Progress in Development Studies vol. 3, pp. 179, 2003.

[7] C. Parmesan and G. Yohe, "A globally coherent fingerprint of climate change impacts across natural systems," Nature, vol. 421, no. 6918, pp. 37-42, 2003.

[8] T. L. Root, J. T. Price, K. R. Hall, S. H. Schneider, C. Rosenzweig, and J. A. Pounds, "Fingerprints of global warming on wild animals and plants," Nature, vol. 421, no. 6918, pp. 57-60, 2003.

[9] R. J. T. Klein, S. Huq, F. Denton, T. E. Downing, R. G. Richels, J. B. Robinson et al., "Inter-relationships between adaptation and mitigation", in Climate change 2007: Impacts, adaptation and vulnerability. Contribution of Working Group II to the Fourth Assessment Report of the Intergovernmental Panel on Climate Change, M. L. Parry, O. F. Canziani, J. P. Palutikof, P. J. van der Linden, and C. E. Hanson, Eds., Cambridge: Cambridge University Press, pp. 745-777, 2007.

[10] G. R. Biesbroek, R. J. Swart, and W. G. M. Knaap, "The mitigation-adaptation dichotomy and the role of spatial planning," Habitat International, vol. 33, pp. 230-237, 2009.

[11] M. M. Betsill and H. Bulkeley, "Looking back and thinking ahead: a decade of cities and climate change research," Local Governments, vol. 12, no. 5, pp. 447-456, 2007

[12] H. Bulkeley, H. Schroeder, K. Jand, J. Zhao, A. Armstrong, S. Y. Chu, and S. Ghosh, "Cities and climate change: The role of institutions, governance and urban planning," World Bank Urban Research Symposium, Marseille, 2009.

[13] F. Barbi and L. C. Ferreira, "Governos locais e mudanças climáticas: ações da Campanha "Cidades pela Proteção do Clima"” em Belo Horizonte-MG, Betim-MG e Porto Alegre-RS, presented at V Enanppas, Florianópolis - SC - Brasil, 4-7 October, 2010.

Fabiana Barbi is a sociologist (Unicamp, Brazil, 2002) and Master's in Environmental Science (University of Sao Paulo, Brazil and York University, Canada, 2007).

She was a visiting researcher at IAS Fudan University, Shanghai (2012). She is a PhD Candidate in Environment and Society at the Centre of Environmental Studies and Research (Nepam) at the State University of Campinas (Unicamp), Brazil. Her research interests are climate change, climate policy, mitigation and adaptation.

Ms. Barbi is a research fellow of the Earth System Governance Project.

Leila da Costa Ferreira is an ecologist (Unesp, Brazil, 1982), Master's in Sociology (Unicamp, Brazil, 1986) and PhD in Social Sciences (Unicamp, Brazil, 1992).

She was a Visiting Professor at Jio Tong University/ Summer Course, Shanghai, China. She is the author of "Idéias para uma Sociologia da Questão Ambiental no Brasil" (São Paulo: Annablume, 2006) and "A Questão Ambiental. Sustentabilidade e Políticas Públicas no Brasil" (São Paulo: Boitempo, 1998). She is a Full Professor at the Institute of Philosophy and Human Sciences (IFCH) and Centre of Environmental Studies and Research (Nepam) at the State University of Campinas (Unicamp), Brazil. Her research interests are environmental sociology, sustainability and interdisciplinarity.

Dr. Ferreira is an associate faculty member of the Earth System Governance Project. 